\title{
PENGOLAHAN DIMSUM CUMI (Loligo sp.) DENGAN PENGGUNAAN KONSENTRASI KECAP ASIN YANG BERBEDA
}

\section{PROCESSING OF CUMI DIMSUM (Loligo sp.) USING A DIFFERENT CONCENTRATION OF SOY SAUCE}

\author{
Basri', Kurnia Sada Harahap ${ }^{1}$, Andiki Yelofeva1 ${ }^{1}$ \\ ${ }^{1}$ Politeknik Kelautan dan Perikanan Dumai, JI. Wan Amir No.1, Kota Dumai, Indonesia \\ "Korespondensi: @gmail.com (Basri) \\ Diterima 23 Februari 2021 - Disetujui 20 Maret 2021
}

\begin{abstract}
ABSTRAK. Cumi-cumi merupakan hasil laut yang banyak terdapat di perairan Indonesia. Beberapa cumi diolah. Cumi-cumi merupakan jenis chepaloda yang dikenal di dunia perdagangan selain sotong dan gurita. Proses pembuatan dimsum dilakukan dengan melalui beberapa tahapan, mulai dari tahap penyiangan, pencucian, penggilingan, pencampuran bumbu, pengepresan, pengukusan, hingga tahap pengemasan dan pelabelan. terlalu amis, tekstur dan rasa elastis yang tidak hambar atau asin. Formulasi terbaik dari 3 perlakuan pembuatan dim sum adalah perlakuan kedua, dengan kode sampel K.2 yaitu penambahan kecap $6 \%$ dan $12 \%$, hal ini dibuktikan dengan uji hedonik oleh 30 panelis yang lebih mengutamakan rasa. warna, rasa dan tekstur produk Dimsum perlakuan ke-2 dengan modal Rp. 98.000 dalam $500 \mathrm{~g}$ dapat menghasilkan 18 cangkir dengan dim sum 126. Keuntungan yang diperoleh Rp 28.000, analisis R / C 3,85.
\end{abstract}

KATA KUNCI: Dimsum, Cumi, Kecap

ABSTRACT. Squid is a marine product that is widely available in Indonesian waters. Some of the squid is processed. Squid is a type of chepaloda known in the world of trade besides cuttlefish and octopus. The process of making dimsum is carried out by going through several stages, starting from the stage of weeding, washing, grinding, mixing the spices, pressing, steaming, and finally the packaging and labeling stages. too fishy, elastic texture and taste that is neither bland nor salty. The best formulation of the 3 treatments in making dim sum is the second treatment, with sample code K.2, namely the addition of $6 \%$ and $12 \%$ soy sauce, this is evidenced by the hedonic test by 30 panelists who prefer the taste, color, flavor and texture of 2nd treatment Dimsum product using a capital of Rp. 98,000 in $500 \mathrm{~g}$ can produce 18 cups with a dim sum of 126. The profit obtained is IDR 28,000, analysis of $R / C 3.85$.

KEYWORDS: Dimsum, Squid, Soy sauce

\section{Pendahuluan}

Potensi perikanan dapat memiliki nilai ekonomi yang sangat menjanjikan dimasa mendatang jika dilakukan intervensi dalam pengelolaan yang tepat. Jenisjenis ikan yang sering ditangkap antara lain adalah tuna, cakalang, selar kuning, kembung, dan cumi- cumi (Effendi \& Oktariza, 2006). Pada musim-musim tertentu hasil tangkapan nelayan sering melimpah. Salah satu jenis hasil perikanan yang sering melimpah pada musim-musim tertentu ialah cumi-cumi.

Cumi-cumi adalah organisme yang termasuk dalam avertebrata dari kelompok Fillum Mollusca Kelas Cephalopoda (kaki di Kepala) yang bertubuh lunak dan menggunakan kepala untuk bergerak (Lumenta, 2017). Bentuk tubuh cumi-cumi adalah simetri bilateral dan dapat dibedakan atas kepala, leher dan mantel/badan. Pada bagian kepala terdapat mulut yang dikelilingi oleh dua tangan panjang (tentakel) dan delapan tangan pendek (Rudiana \& Pringgenies, 2004).

Cumi-cumi mengandung sekitar $80 \%$ protein miofibril, $12-20 \%$ protein mioplasma dan $2-3 \%$ protein miostroma (Lindawanti, 2017). Tingginya kandungan protein miofibril pada cumicumi 
memungkinkan untuk membekukan produk, sehingga memudahkan dalam proses produk cumi-cumi seperti nugget cumi, bakso cumi, dan dimsum cumi. Dim sum merupakan produk olahan yang biasa disajikan sebagai makanan camilan dan telah dikenal luas oleh masyarakat. Umumnya dimsum yang ada di pasaran saat ini menggunakan bahan baku ayam, udang, daging sapi atau ikan tenggir, dan cumi cumi.

Dim Sum adalah istilah dari bahsa kantonis yang artinya adalah "makanan kecil ". Biasanya dim sum dimakan sebagai sarapan, namun karena dimsum populer kedunia dari Hongkong maka istilah dimsum lebih populer dibandingkan dianxin di Indonesia dim sum sangat lah di gemari karena Banyak faktor yang menyebabkan dimsum disukai di Indonesia selain karena estetika keindahan bentuknya, seperti faktor dimsum memiliki rasa yang enak, banyak variasi, dimsum juga merupakan alternatif makanan sehat karena teknik pengolahan dimsum sebagian besar adalah dengan cara dikukus. Tujuan dari penelitian ini yaitu untuk menentukan penambahan kecap asin yang efektif pada dimsum dengan uji hedonik dengan parameter warna, aroma, tekstur dan rasa.

\section{Bahan dan Metode}

Peralatan yang digunakan pada proses pengolahan dimsum cumi adalah sebagai berikut Baskom Pisau Dandang Kompor Talenan Nampan. Metode yang digunakan adalah metode bersifat ekperimental yang dimaksudkan untuk mengetahui ada tidaknya akibat dari sesuatu yang dikenakan pada subjek yang diamati. Pembuatan dimsum ini dilakukan dengan 3 perlakuan yang berbeda yaitu masing-masing adonan diberikan formulasi konsentrasi kecap asin yang berbeda, sebagai berikut perlakukan :

\section{Tabel 1. Kode perlakuan pada pengujian}

\begin{tabular}{ll} 
Kode Perlakuan & Konsentrasi Kecap Asin \\
\hline K.1 & $6 \%$ \\
K.2 & $12 \%$ \\
K.3 & $16 \%$ \\
\hline
\end{tabular}

Cumi-cumi sebelum digunakan dilakukan uji deskripsi, untuk mengetahui kelayakannya untuk dijadikan bahan baku Pengujian deskripsi menggunakan lembar uji deskripsi yang dilakuakn oleh 6 orang panelis (Sugiyono, 2009). Setelah itu dilakukan penghitungan rendemen terlebih dahulu untuk mengetahui berapa banyak daging yang dapat digunakan sebagai bahan baku.

Parameter yang diamati dalam praktik pembuatan dimsum cumi ini adalah uji hedonic berupa rasa, aroma, warna dan tekstur, dengan melakukan uji hedonik sebelumnya yang dilakukan 30 orang tidak terlatih (Lestari et al., 2019). Selanjutnya dilakukan analisa usaha untuk mengetahui kelayakan usaha dimsum yang dilakukan.

\section{Pengolahan Dimsum Cumi Cumi}

Pengolahan dimsum cumi cumi memiliki beberapa tahapan yaitu penerimaan bahan baku, penyiangan, pencucian, penghalusan, pencampuran bumbu dan kecap asin, pembentukan pengukusan, dan pengemasan, bahan baku yang diterima termasuk bahaan baku dengan mutu terbaik dengan keadaan kenapamkan cumi cumi mata jernih, tidak berbau, berwarna cerah,

Selanjutnya bahan baku di buang kepala dan tinta hingga bersih kemudian di cuci hingga bersih lalu daging cumi cumi di lumatkan dan di campurkan dengan bahan bahan seperti tepung tapioka, merica bubuk, penyedap rasa, wortel dan penambahan konsentrasi kecap asin yang berbeda pada 3 adonan yang terpisah, dan setelah di lakukan penambahan bahan kemudian semua bahan di aduk rata hingga kalis dan setelah kalis dilakukan pembentukan adonan dengan cara membungkus adonan dengan kulit lumpia kamudian di bentuk dengan motif tertentu seperti dimsum pada umumnya kamudian dilakukan pengukusan selama 15 menit dan di lakukan pengemasan. 


\section{Hasil dan Pembahasan}

Pengujian dilakukan oleh 6 orang panelis standar. Panelis diminta untuk memberikan tanggapan pribadi tentang kesukaan atau ketidaksukaan dalam berbagai skala angka yang diberikan dalam lembar penilaian. Tujuan dari uji hedonik adalah untuk mengetahui respon panelis terhadap sifat mutu yang umum, misalnya rasa, aroma, warna dan tekstur (Rahayu, 2001). Skala hedonik yang digunakan berkisar antara 1-5 dimana (1) sangat tidak suka; (2) tidak suka; (3) netral; (4) suka; dan (5) sangat suka.

\section{A. Rasa}

Berdasarkan hasil pengujian dan perhitungan yang dilakukan, panelis diperoleh nilai $\mathrm{K} .1=3$ (Netral), K.2 = 4 (suka) dan K.3=2 (tidak suka). Berdasarkan nilai tersebut menunjukkan bahwa panelis lebih suka dengan dimsum pada perlakuan kedua dengan kode sampel K.2 yaitu dengan penambahan kecap asin $12 \%$ dan $6 \%$. Hal ini menunjukkan bahwa panelis lebih banyak menyukai rasa dimsum yang enak (tidak terlalu asin dan tidak terlalu hampar) (Agusandi \& Lestari, 2013). Semakin banyak penambahan kecap asin mempengaruhi rasa.

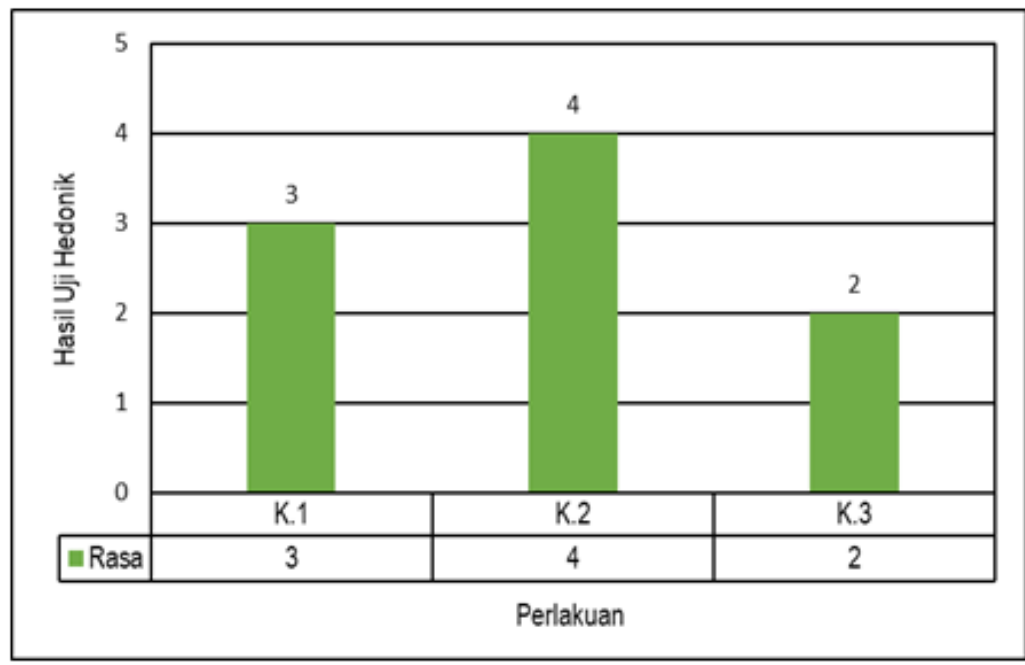

Gambar 1. Histogram nilai rasa dimsum cumi

\section{B. Aroma}

Dari nilai grafik yang ditunjukkan Gambar. menunjukkan bahwa panelis lebih menyukai dimsum perlakuan kedua, karena tidak terlalu amis dan masih ada aroma khas dari cumi-cuminya. Hal tersebut menunjukkan bahwa semakin tinggi formulasi kecap asin yang diberikan akan mempengaruhi aroma dari cumi-cumi yang digunakan (Agusandi \& Lestari, 2013). Semakin tinggi jumlah kecap asin yang ditambahkan akan membuat aroma amis ikan hilang. 


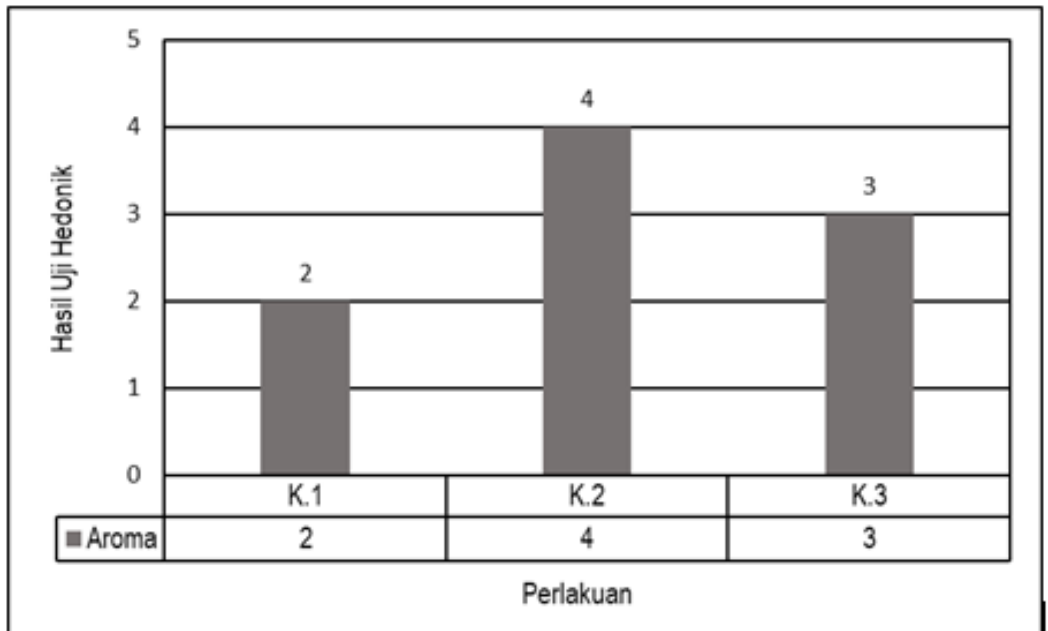

Gambar 2. Histogram nilai aroma dimsum cumi

\section{Warna}

Pada pengujian hedonik panelis lebih suka terhadap dimsum yang berwana putih, yaitu pada dimsum perlakuan pertama (K.2, dengan nilai 4 (suka). Hal itu dikarenakan perlakuan pertama dengan nilai 3 (Netral) memiliki warna yang bagus (Agusandi \& Lestari, 2013), sedangkan perlakuan ketiga juga memiliki nilai pengujian yang sama dengan perlakuan satu, hanya saja warna yang dihasilkan lebih gelap dan kurang menarik.

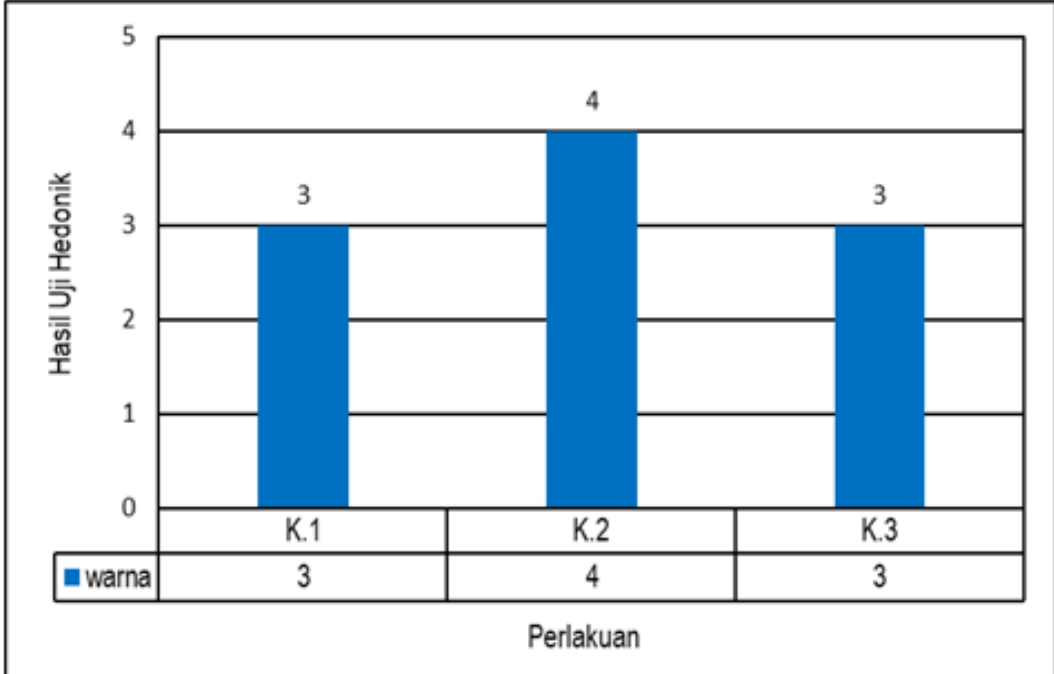

Gambar 3. Histogram nilai warna dimsum cumi

\section{Tekstur}

Nilai tertinggi dari teksur dimsum terdapat pada perlakuan kedua (K.2) dengan nilai 4 (Suka), sedangkan nilai perlakuan pertama (K.1) dan ketiga (K.3) adalah 3 (Netral). Panelis lebih menyukai tekstur dimsum perlakuan kedua dengan formulasi kecap $6 \%$ dan $12 \%$ yaitu dengan tekstur yang tidak terlalu lembut dan juga tidak terlalu keras. 


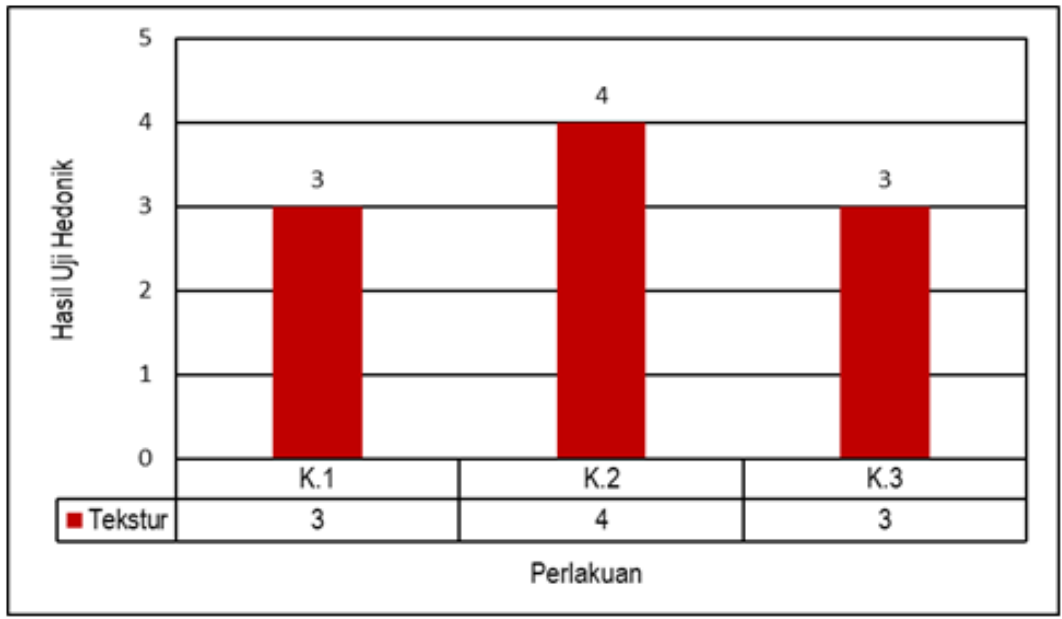

Gambar 4. Histogram nilai tekstur dimsum cumi

\section{Kesimpulan}

Berdasarkan uji hedonik yang telah dilakukan, panelis lebih menyukai dimsum yang memiliki warna yang cerah, aroma yang tidak terlalu amis, tekstur yang elastis dan rasa yang tidak hambar dan tidak pula asin. formulasi terbaik dalam dari 3 perlakuan dalam pembuatan dimsum adalah perlakuan ke 2, dengan kode sampel K.2 yaitu dengan penambahan kecap asin $6 \%$ dan $12 \%$, hal tersebut dibuktikan berdasarkan uji hedonikoleh 30 panelis yang lebih menyukai rasa, warna, aroma dan tekstur perlakuan ke2.

\section{DAFTAR PUSTAKA}

Agusandi, A. S., \& Lestari, S. D. (2013). Pengaruh Penambahan Tinta Cumi-Cumi (Loligo Sp) Terhadap Kualitas Nutrisi Dan Penerimaan Sensoris Mi Basah. Fishtech, 2(1), 22-37.

Effendi, I., \& Oktariza, W. (2006). Manajemen Agribisnis Perikanan. Penerbit Swadaya.

Lestari, P., Widiastuti, I., \& Lestari, S. (2019). Pengaruh Komposisi Rumput Laut (Eucheuma Cottonii) dan Tepung Beras Terhadap Sifat Kimia dan Sensoris Masker Wajah. Jurnal FishtecH, 7(2), 111119.

Lindawanti. (2017). Absorbsi Logam Berat Kadmium (Cd) Pada Cumi Cumi (Loligo Sp) Di Pulau LaeLae. UIN ALAUDDIN MAKASSAR.

Lumenta, C. (2017). Avertebrata air (C. Lumenta (ed.)). Unsrat Press.

Rahayu, W. P. (2001). Penuntun Praktikum Penilaian Organoleptik. Jurusan Teknologi Pangan.

Rudiana, E., \& Pringgenies, D. (2004). Morfologi dan Anatomi Cumi-Cumi Loligo duvauceli yang Memancarkan Cahaya. ILMU KELAUTAN: Indonesian Journal of Marine Sciences, 9(2), 96-100.

Sugiyono. (2009). Metode Penelitian Kualitatif, Kuantitatif, dan R\&D. Alfabeta. 
